\title{
Metal Allergy Screening Prior to Joint Arthroplasty and Its Influence on Implant Choice: A Delphi Consensus Study Amongst Orthopaedic Arthroplasty Surgeons
}

\author{
Arif Razak, MRCS, Ananthan Dave Ebinesan, MRCS, and Charalambos Panayiotou Charalambous, MD, FRCS
} Department of Orthopaedic Surgery, Blackpool Victoria Hospital, Lancashire, UK

\begin{abstract}
Purpose: This study was undertaken to obtain a consensus amongst joint arthroplasty experts with regards to metal allergy screening prior to joint arthroplasty and the choice of implant in patients with potential metal allergy.

Materials and Methods: A web based Delphi consensus study was used including orthopaedic surgeons that had previously published on the topic of knee, hip or shoulder arthroplasty. Two rounds of questionnaires were sent via electronic mail. Consensus was considered reached if agreement was $60 \%$ or higher.

Results: Eighteen surgeons responded to the first and 17 to the second round of questionnaires. There was consensus that patients having metal arthroplasty surgery should not be routinely questioned about metal allergy prior to surgery. There was consensus that patch testing is not necessary even if metal allergy is suspected. Most respondents agreed in proceeding with cobalt chromium or stainless steel implant in patients suspected of metal allergy regardless of the results of cutaneous patch testing.

Conclusions: This consensus study suggests that routine metal allergy screening prior to joint arthroplasty is not essential. The use of traditional cobalt chromium/stainless steel implants is recommended regardless of the patient's metal allergy status based on expert opinion through this study.
\end{abstract}

Keywords: Arthroplasty, Metal allergy, Delphi study

\section{Introduction}

Cutaneous metal allergy as detected by patch testing affects $10 \%$ to $17 \%$ of the population ${ }^{1-5)}$. This is mainly to metals such as nickel, palladium, cobalt, and chrome. Joint arthroplasty using metallic implants is one of the most common elective orthopaedic operations with 79,516 primary total knee replacements (TKR) and 71,672 primary total hip replacements (THR) performed in England and Wales in $2011^{6)}$. Therefore, metal allergy screening

Received May 13, 2013; Revised September 16, 2013;

Accepted October 8, 2013

Correspondence to: Charalambos Panayiotou Charalambous, MD, FRCS

Department of Orthopaedic Surgery, Blackpool Victoria Hospital,

Whinney Heys Rd, Blackpool, Lancashire FY3 8NR, UK

Tel: +44-1253-300000, Fax: +44-1253-655983

E-mail: bcharalambos@hotmail.com

This is an Open Access article distributed under the terms of the Creative Commons Attribution Non-Commercial License (http://creativecommons.org/licenses/by-nc/3.0/) which permits unrestricted non-commercial use, distribution, and reproduction in any medium, provided the original work is properly cited. in joint arthroplasty, particularly in knee joint arthroplasty, can potentially cause surgical delays and additional costs.

Although rare cutaneous reactions have been reported following deep orthopaedic implant usage, the role of metal allergy to ongoing joint pain and early aseptic loosening is still controversial $^{7-10)}$. Similarly, there is controversy as to whether cutaneous allergy can be indicative of an allergy to deep seated implants ${ }^{4,11,12)}$.

There are several recommendations available on managing patients with potential metal allergy undergoing joint arthroplasty. Schalock et al. ${ }^{13)}$ recommended any patient with a prior history of reported cutaneous metal allergy should be patch tested prior to device implantation. Granchi et al. ${ }^{14)}$ also recommended patch testing for any patient with previous signs or symptoms of metal allergy. Patients with positive skin reaction should not have an implant containing the metal allergen if possible ${ }^{14)}$.

The aim of our study was to obtain a consensus among joint arthroplasty surgeons who are considered experts in their field within the UK on metal allergy screening prior to joint arthroplasty surgery and its implication on implant choice. 


\section{Materials and Methods}

The Delphi technique was used to combine expert opinion anonymously into a group consensus. The Delphi method involves questionnaires being given to a panel of experts with regards to a given topic, in this case metal allergy and joint arthroplasty. This was repeated until a consensus was obtained amongst this panel.

\section{Invited Experts}

Ninety joint arthroplasty experts in the UK were identified through a PubMed/Medline database search. They were selected based on these criteria: recent publications on knee/hip/shoulder joint arthroplasty topics in a PubMed indexed journal and currently working as an orthopaedic surgeon in an NHS hospital within the UK. Sixty experts were knee and/or hip arthroplasty surgeons and the other 30 experts were shoulder/upper limb arthroplasty surgeons. The initial online search for the experts was made on the PubMed/Medline database with these keywords:

Table 1. First Round Questionnaire

\begin{tabular}{|c|c|c|}
\hline No. & Question & Answer \\
\hline 1 & $\begin{array}{l}\text { Should every patient having arthroplasty surgery be asked } \\
\text { about metal allergy prior to surgery? }\end{array}$ & $\begin{array}{l}\text { Yes } \\
\text { No }\end{array}$ \\
\hline 2 & $\begin{array}{l}\text { Which of the following would you consider indicative } \\
\text { of a metal allergy in a patient being listed for joint } \\
\text { arthroplasty? (pick one or more answers) }\end{array}$ & $\begin{array}{l}\text { Localised blistering when in contact with metal/metal jewellery } \\
\text { Localised hives when in contact with metal/metal jewellery } \\
\text { Localised rash when in contact with metal/metal jewellery } \\
\text { Localised itching when in contact with metal/metal jewellery } \\
\text { Localised swelling when in contact with metal/metal jewellery } \\
\text { Generalised blistering when in contact with metal/metal jewellery } \\
\text { Generalised hives when in contact with metal/metal jewellery } \\
\text { Generalised body rash when in contact with metal/metal jewellery } \\
\text { Generalised body itching when in contact with metal/metal jewellery } \\
\text { Generalised body swelling when in contact with metal/metal jewellery } \\
\text { Systemic anaphylactic reactions (e.g. throat and tongue swelling, hypotension, } \\
\text { wheeziness) } \\
\text { Family history of metal allergy } \\
\text { None } \\
\text { Other }\end{array}$ \\
\hline 3 & $\begin{array}{l}\text { If a metal allergy is suspected in a patient about to } \\
\text { undergo joint arthroplasty surgery, what would be your } \\
\text { next step? }\end{array}$ & $\begin{array}{l}\text { Proceed with surgery (cobalt chromium/stainless steel implant which contain } \\
\text { traces of nickel) } \\
\text { Proceed with surgery (non cobalt chromium/stainless steel implant [e.g. } \\
\text { titanium or other nickel free implant]) } \\
\text { Refer for patch testing to determine the metal allergens prior to surgery } \\
\text { Other }\end{array}$ \\
\hline 4 & $\begin{array}{l}\text { How would you manage a patient whose patch test was } \\
\text { positive for cobalt, chromium or nickel? }\end{array}$ & $\begin{array}{l}\text { Use cobalt chromium/stainless steel implant anyway (contain traces of nickel) } \\
\text { Use titanium/other nickel free implant } \\
\text { Other }\end{array}$ \\
\hline 5 & $\begin{array}{l}\text { How would you manage a patient if patch testing was } \\
\text { negative for a metal allergy but the patient gives a } \\
\text { history of local reaction to metal/metal jewellery? }\end{array}$ & $\begin{array}{l}\text { Use cobalt chromium/stainless steel implant anyway (contain traces of nickel) } \\
\text { Use titanium/other nickel free implant } \\
\text { Other }\end{array}$ \\
\hline 6 & $\begin{array}{l}\text { How would you manage a patient if patch testing was } \\
\text { negative for a metal allergy but the patient gives a } \\
\text { history of generalised reaction to metal/metal jewellery? }\end{array}$ & $\begin{array}{l}\text { Use cobalt chromium/stainless steel implant anyway (contain traces of nickel) } \\
\text { Use titanium/other nickel free implant } \\
\text { Other }\end{array}$ \\
\hline
\end{tabular}


"knee arthroplasty", "hip arthroplasty", "shoulder arthroplasty", and "joint replacements". The publication dates were set between January 2000 and March 2012 inclusive. The senior author of the publication was selected. The author's email address was obtained either from the publication or through Google search. The administered questionnaires were prepared on the survey monkey website (www.surveymonkey.com). A cover letter explaining the details of the study together with the website link to this questionnaire was sent to the authors' email address. No incentives were offered for participating in the study.

Table 2. Second Round Questionnaire

\begin{tabular}{|c|c|c|c|}
\hline No. & Question & Answer & \\
\hline 1 & $\begin{array}{l}\text { Majority said that patient having arthroplasty surgery should not } \\
\text { be routinely asked about metal allergy prior to surgery. Do you } \\
\text { agree? }\end{array}$ & Yes/No & \\
\hline 2 & $\begin{array}{l}\text { Majority considered the following signs/symptoms to be indicative } \\
\text { of a metal allergy in a patient being listed for joint arthroplasty. } \\
\text { Do you agree? }\end{array}$ & $\begin{array}{l}\text { Localised blistering when in contact with metal/metal } \\
\text { jewellery } \\
\text { Localised hives when in contact with metal/metal } \\
\text { jewellery } \\
\text { Localised rash when in contact with metal/metal } \\
\text { jewellery } \\
\text { Generalised body swelling when in contact with } \\
\text { metal/metal jewellery } \\
\text { Systemic anaphylactic reactions }\end{array}$ & Yes/No/Other \\
\hline 3 & $\begin{array}{l}\text { Majority did not feel that the following signs/symptoms to be } \\
\text { considered indicative of a metal allergy in a patient being listed } \\
\text { for joint arthroplasty. Do you agree? }\end{array}$ & $\begin{array}{l}\text { Localised itching when in contact with metal/metal } \\
\text { jewellery } \\
\text { Localised swelling when in contact with metal/metal } \\
\text { jewellery } \\
\text { Generalised blistering when in contact with metal/ } \\
\text { metal jewellery } \\
\text { Generalised hives when in contact with metal/metal } \\
\text { jewellery } \\
\text { Generalised body rash when in contact in metal/ } \\
\text { metal jewellery } \\
\text { Generalised body itching when in contact with metal/ } \\
\text { metal jewellery } \\
\text { Family history of metal allergy }\end{array}$ & Yes/No/Other \\
\hline 4 & $\begin{array}{l}\text { Majority would proceed with surgery (cobalt chromium/stainless } \\
\text { steel implant) even if a metal allergy is suspected in a patient } \\
\text { about to undergo joint arthroplasty. Do you agree? }\end{array}$ & Yes/No/Other & \\
\hline 5 & $\begin{array}{l}\text { Majority would still use cobalt chromium/stainless steel implant } \\
\text { (contain traces of nickel) in a patient whose patch test was } \\
\text { positive for cobalt, chromium or nickel. Do you agree? }\end{array}$ & Yes/No/Other & \\
\hline 6 & $\begin{array}{l}\text { Majority would still use cobalt chromium/stainless steel implant } \\
\text { (contain traces of nickel) in a patient whose patch test was } \\
\text { negative for a metal allergy but the patient gives a history of local } \\
\text { reaction to metal/metal jewellery. Do you agree? }\end{array}$ & Yes/No/Other & \\
\hline 7 & $\begin{array}{l}\text { Majority would still use cobalt chromium/stainless steel implant } \\
\text { (contain traces of nickel) in a patient whose patch test was } \\
\text { negative for a metal allergy but the patient gives a history of } \\
\text { generalised reaction to metal/metal jewellery. Do you agree? }\end{array}$ & Yes/No/Other & \\
\hline
\end{tabular}




\section{1) Questionnaire (Table 1)}

Two separate questionnaires were made, one knee and hip questionnaire and one shoulder questionnaire. The knee and hip questionnaire was sent to the knee/hip expert group and the shoulder questionnaire was sent to the shoulder expert group. The questions in the 2 questionnaires were the same apart from the type of joint (knee, hip, shoulder) they were referring to. The questionnaire enquired about the joint arthroplasty experience of the recipients, their views on various allergy signs and symptoms, investigations for metal allergy prior to joint arthroplasty and the influence of such investigations on implant choice. Experts who did not respond initially received the questionnaire again with a 2 week interval until a response was obtained. Overall, the questionnaire was sent to the non-responders 4 times over a 3 month period.

The responses from the first round of questionnaires were analysed and the second round of questionnaires were formulated based on the most popular answers.

\section{2) Questionnaire (Table 2)}

In the second round questionnaire, the experts who replied to the first round were contacted again. They were asked whether or not they agreed with the most popular responses of the first questionnaire round. The questionnaire was sent to the nonresponders with repeated attempts up to 4 times over a period of 2 months.

Eighteen experts completed the first round questionnaire and 17 of those completed the second round questionnaire.

\section{Results}

\section{Round 1}

The responders were 16 knee and/or hip surgeons and 2 shoulder surgeons (Table 3). Their responses to the first round of questionnaires are shown in Table 4.

Eleven experts agreed that patients should not be routinely asked about metal allergy prior to surgery. At least 10 experts considered localised blistering, rash or systemic anaphylactic reactions when in contact with metal as indicative of a metal allergy. Seven experts would proceed with surgery (cobalt chromium or stainless steel implants) if a metal allergy is suspected in patients about to undergo joint arthroplasty surgery. Six experts, however, would refer these patients for patch testing before surgery. In a patient with positive patch test for cobalt, chromium or nickel, 7 experts would still use cobalt chromium or stainless steel implant while 6 experts would use titanium or other nickel free implant. In a patient with negative patch test but with a history of local reaction to metal, 16 experts would use cobalt chromium or stainless steel implant. In a patient with negative patch test but with a history of generalised reaction to metal, 14 experts would use cobalt chromium or stainless steel implant.

\section{Round 2}

The responders were 16 knee and/or hip surgeons and 1 shoulder surgeon. Their responses to the second round of questionnaires are shown in Table 5.

Sixteen experts agreed that patients should not be routinely asked about metal allergy prior to surgery. Fourteen experts agreed on localised blistering, hives and rash, generalised body swelling and systemic anaphylactic reactions when in contact with metal as indicative of metal allergy. Fourteen experts agreed that they would proceed with cobalt chromium or stainless steel implant even if a metal allergy is suspected. Twelve experts agreed that they would still use cobalt chromium or stainless steel implant in patients with positive patch test for cobalt, chromium or nickel. The majority of experts would still use cobalt chromium or stainless steel implant in patients with a negative patch test result but with a history of localised (16 experts) or generalised reactions (15 experts) to metal.

Table 3. The Number of Joint Arthroplasty Done by a Surgeon in a Year

\begin{tabular}{|c|c|c|c|}
\hline Surgeon & Knee arthroplasty & Hip arthroplasty & Shoulder arthroplasty \\
\hline 1 & 0 & $>20$ & \\
\hline 2 & $11-20$ & $6-10$ & \\
\hline 3 & $>20$ & $>20$ & \\
\hline 4 & $>20$ & $>20$ & \\
\hline 5 & $>20$ & 0 & \\
\hline 6 & $6-10$ & $>20$ & \\
\hline 7 & 0 & $>20$ & \\
\hline 8 & $>20$ & $>20$ & \\
\hline 9 & $>20$ & 0 & \\
\hline 10 & $>20$ & 0 & \\
\hline 11 & $>20$ & $>20$ & \\
\hline 12 & 0 & $>20$ & \\
\hline 13 & $>20$ & $>20$ & \\
\hline 14 & $>20$ & $>20$ & \\
\hline 15 & $11-20$ & $>20$ & \\
\hline 16 & $>20$ & $>20$ & \\
\hline 17 & & & $>20$ \\
\hline 18 & & & $>20$ \\
\hline
\end{tabular}


190 Razak et al. Metal Allergy Screening Prior to Joint Arthroplasty: A Delphi Study

Table 4. The First Round Questionnaire Result

\begin{tabular}{|c|c|c|c|}
\hline No. & Question & Answer & Response $(\mathrm{n}=18)$ \\
\hline \multirow[t]{2}{*}{1} & \multirow{2}{*}{$\begin{array}{l}\text { Should every patient having arthroplasty } \\
\text { surgery be asked about metal allergy prior } \\
\text { to surgery? }\end{array}$} & Yes & $7(39)$ \\
\hline & & No & $11(61)$ \\
\hline \multirow[t]{14}{*}{2} & \multirow{14}{*}{$\begin{array}{l}\text { Which of the following would you consider } \\
\text { indicative of a metal allergy in a patient } \\
\text { being listed for joint arthroplasty? (pick } \\
\text { one or more answers) }\end{array}$} & Localised blistering when in contact with metal/metal jewellery & $11(61)$ \\
\hline & & Localised hives when in contact with metal/metal jewellery & $11(61)$ \\
\hline & & Localised rash when in contact with metal/metal jewellery & $10(55)$ \\
\hline & & Localised itching when in contact with metal/metal jewellery & $4(22)$ \\
\hline & & Localised swelling when in contact with metal/metal jewellery & $5(28)$ \\
\hline & & Generalised blistering when in contact with metal/metal jewellery & $7(39)$ \\
\hline & & Generalised hives when in contact with metal/metal jewellery & $8(44)$ \\
\hline & & Generalised body rash when in contact with metal/metal jewellery & $8(44)$ \\
\hline & & Generalised body itching when in contact with metal/metal jewellery & $6(33)$ \\
\hline & & Generalised body swelling when in contact with metal/metal jewellery & $9(50)$ \\
\hline & & $\begin{array}{l}\text { Systemic anaphylactic reactions (e.g. throat and tongue swelling, } \\
\text { hypotension, wheeziness) }\end{array}$ & $12(67)$ \\
\hline & & Family history of metal allergy & $2(11)$ \\
\hline & & None & $3(17)$ \\
\hline & & Other & $\begin{array}{l}1(6) \\
\text { "Placing the implant on the thigh for } 1 \text { hour will produce an } \\
\text { outline in red of the implant." }\end{array}$ \\
\hline \multirow[t]{4}{*}{3} & \multirow{4}{*}{$\begin{array}{l}\text { If a metal allergy is suspected in a patient } \\
\text { about to undergo joint arthroplasty } \\
\text { surgery, what would be your next step? }\end{array}$} & $\begin{array}{l}\text { Proceed with surgery (cobalt chromium/stainless steel implant which } \\
\text { contain traces of nickel) }\end{array}$ & $7(39)$ \\
\hline & & $\begin{array}{l}\text { Proceed with surgery (non cobalt chromium/stainless steel implant [e.g. } \\
\text { titanium or other nickel free implant]) }\end{array}$ & 0 \\
\hline & & Refer for patch testing to determine the metal allergens prior to surgery & $6(33)$ \\
\hline & & Other & $\begin{array}{l}5 \text { (28) } \\
\text { "If localised skin allergy, I would proceed with arthroplasty and } \\
\text { not change my normal implant. If systemic reaction, I would } \\
\text { seek advice from 'allergy specialists' i.e., allergen testing." } \\
\text { "I would implant a small metal disc of the joint replacement } \\
\text { metal which was easily removable if allergy symptoms } \\
\text { occurred } 3 \text { months before definitive joint replacement." } \\
\text { "Generally priced to surgery with nickel free etc if patient } \\
\text { wishes despite recommendation to avoid surgery." } \\
\text { "Ask the patient more details." } \\
\text { "I only consider special implants if the patient raises it as a } \\
\text { specific concern and wants alternative." }\end{array}$ \\
\hline \multirow[t]{3}{*}{4} & \multirow{3}{*}{$\begin{array}{l}\text { How would you manage a patient whose } \\
\text { patch test was positive for cobalt, } \\
\text { chromium or nickel? }\end{array}$} & $\begin{array}{l}\text { Use cobalt chromium/stainless steel implant anyway (contain traces of } \\
\text { nickel) }\end{array}$ & $7(39)$ \\
\hline & & Use titanium/other nickel free implant & $6(33)$ \\
\hline & & Other & $\begin{array}{l}5 \text { (28) } \\
\text { "If systemic clinical picture of allergy, I would use nickel free } \\
\text { implant." } \\
\text { "I would implant a small metal disc of the joint replacement } \\
\text { metal which was easily removable if allergy symptoms } \\
\text { occurred } 3 \text { months before definitive joint replacement." } \\
\text { "Oxinium." } \\
\text { "Most metal allergies are cutaneous allergies and in this } \\
\text { instance I would proceed with my usual choice of TKR. } \\
\text { If the patient has a more severe allergy i.e. Anaphylaxis of } \\
\text { generalised urticaria I would consider an alternative metal." } \\
\text { "Never had that situation. If they wanted I would discuss the } \\
\text { pros and cons of using an unfamiliar implant." }\end{array}$ \\
\hline \multirow[t]{3}{*}{5} & \multirow{3}{*}{$\begin{array}{l}\text { How would you manage a patient if patch } \\
\text { testing was negative for a metal allergy but } \\
\text { the patient gives a history of local reaction } \\
\text { to metal/metal jewellery? }\end{array}$} & $\begin{array}{l}\text { Use cobalt chromium/stainless steel implant anyway (contain traces of } \\
\text { nickel) }\end{array}$ & $16(89)$ \\
\hline & & Use titanium/other nickel free implant & $1(6)$ \\
\hline & & Other & $\begin{array}{l}1(6) \\
\text { "Standard implant as the oxinium does not have good general } \\
\text { options." }\end{array}$ \\
\hline \multirow[t]{3}{*}{6} & \multirow{3}{*}{$\begin{array}{l}\text { How would you manage a patient if patch } \\
\text { testing was negative for a metal allergy but } \\
\text { the patient gives a history of generalised } \\
\text { reaction to metal/metal jewellery? }\end{array}$} & $\begin{array}{l}\text { Use cobalt chromium/stainless steel implant anyway (contain traces of } \\
\text { nickel) }\end{array}$ & $14(78)$ \\
\hline & & Use titanium/other nickel free implant & $2(11)$ \\
\hline & & Other & $\begin{array}{l}2(11) \\
\text { "I would implant a small metal disc of the joint replacement } \\
\text { metal which was easily removable if allergy symptoms } \\
\text { occurred } 3 \text { months before definitive joint replacement." } \\
\text { "Get advice as I have not seen this problem." }\end{array}$ \\
\hline
\end{tabular}

Values are presented as mean (\%).

TKR: total knee replacements. 
Table 5. The Second Round Questionnaire Result

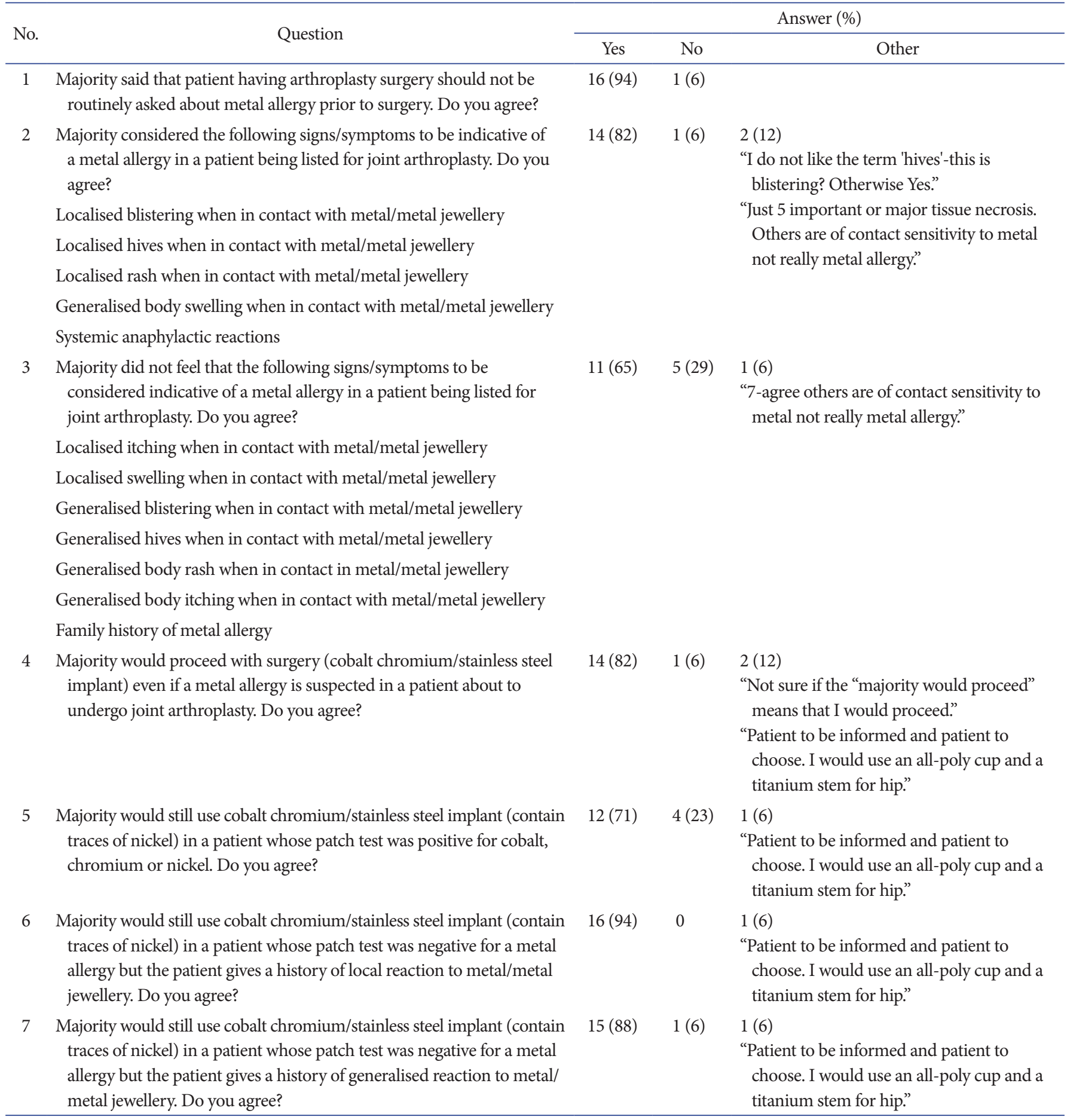

\section{Discussion}

The implications of metal allergy to joint arthroplasty surgery remain a topic that is still not fully appreciated in research. This study was carried out to obtain a consensus amongst joint arthro- plasty surgeons on metal allergy screening prior to joint arthroplasty surgery and its implication on implant choice.

The Delphi method has been widely used as a research tool in many fields such as healthcare and education ${ }^{15}$. It involves several rounds of questionnaires sent to a panel of experts until a consen- 
sus is reached. The Delphi method is often used for an issue for which there is limited scientific or clinical evidence, and hence the opinions of experts are sought. There are several advantages of the Delphi methodology. Each expert is unaware as to who the remaining participants are, hence any bias in expression of opinion is limited. The Delphi method also makes it easier to bring together a group of experts, and there is no geographical limit as to the participants involved ${ }^{16}$. Although absolute agreement is often not achieved, a predefined level of agreement amongst experts is necessary for consensus to be reached. There is no standard cut off point for consensus with a cut off limit of $51 \%{ }^{17)}$ to $70 \%$ employed previously ${ }^{15,18}$. Because of our small number of experts, we used a minimum of $60 \%$ of experts' agreement as a consensus.

Our results suggest that although absolute agreement could not be obtained, a consensus (defined as $>60 \%$ agreement) was reached for most of the issues examined. This included that patients having metal arthroplasty should not be routinely questioned about metal allergy prior to surgery. It seems the panel felt that patients with troublesome history of metal allergy would offer this history when asked about allergies in general and hence specific questioning may not be essential. Amongst the signs of metal allergy presented to the panel, only localised blistering, hives and/or rash, generalised body swelling and systemic anaphylactic reactions when in contact with a metal were considered indicative of a potential metal allergy, with milder reactions not considered significant.

The panel agreed to proceed with traditional cobalt-chromium/ stainless steel implants in patients who report local or generalised reactions to metal or jewellery but have negative patch testing. Interestingly, however, a consensus level was also reached in using traditional cobalt-chromium/stainless steel implants in patients patch testing positive for cobalt, chromium or nickel. The panel also felt that even if a metal allergy is suspected, a patch test is not necessary to be done to confirm the presence of metal allergy. These responses may signify the lack of strong evidence as to the role of metal allergy on ongoing joint pain and early aseptic loosening $^{7-10)}$, but also whether cutaneous allergy can be indicative of an allergy to deep seated implants, ${ }^{4,11,12}$. A systematic review and meta-analysis on metal sensitivity testing in patients undergoing joint arthroplasty showed that its predictive value was not statistically proven even though the paper suggested that patients with a history of metal allergy should be patch tested. It is important to note that our study is based on personal opinion of experts rather than scientific evidence ${ }^{14}$. Following the consensus reached here, we could avoid unnecessary extra costs for patch testing and the use of non-standard metal implants such as titanium implants.

A limitation of this study is that only $20 \%$ of the surgeons contacted responded to the first round questionnaire. Nevertheless, as it is a Delphi study, the quality of experts' opinions is more important than the actual response rate. The acceptable sample size can be variable and one Delphi study has been reported with only five experts on the panel ${ }^{19)}$. The fact that all but one participant of the 1st round responded to the 2 nd round gives extra strength to our results and conclusions. To our best knowledge, this is the first time a Delphi approach has been used to reach a consensus amongst arthroplasty experts on important metal allergy issues, which again gives high value to our findings.

\section{Conclusions}

Our consensus study suggests that routine metal allergy screening prior to joint arthroplasty is not essential. The use of traditional cobalt chromium/stainless steel implants is recommended regardless of the patient's metal allergy status based on this consensus study.

\section{Conflict of Interest}

No potential conflict of interest relevant to this article was reported.

\section{References}

1. Gawkrodger DJ. Metal sensitivities and orthopaedic implants revisited: the potential for metal allergy with the new metalon-metal joint prostheses. Br J Dermatol. 2003;148:1089-93.

2. Forte G, Petrucci F, Bocca B. Metal allergens of growing significance: epidemiology, immunotoxicology, strategies for testing and prevention. Inflamm Allergy Drug Targets. 2008;7:145-62.

3. Beecker J, Gordon J, Pratt M. An interesting case of joint prosthesis allergy. Dermatitis. 2009;20:E4-9.

4. Thienpont E, Berger Y. No allergic reaction after TKA in a chrome-cobalt-nickel-sensitive patient: case report and review of the literature. Knee Surg Sports Traumatol Arthrosc. 2013;21:636-40.

5. Thyssen JP, Menne T. Metal allergy: a review on exposures, penetration, genetics, prevalence, and clinical implications. Chem Res Toxicol. 2010;23:309-18.

6. National Joint Registry (NJR). 9th Annual Report 2012 [Internet]. Hemel Hempstead: National Joint Registry Centre; 
2012 [cited 2013 Nov 10]. Available from: http://www.njrcentre.org.uk/

7. Van Opstal N, Verheyden F. Revision of a tibial baseplate using a customized oxinium component in a case of suspected metal allergy: a case report. Acta Orthop Belg. 2011;77:6915.

8. Thomas P, Thomas M, Summer B, Dietrich K, Zauzig M, Steinhauser E, Krenn V, Arnholdt H, Flaig MJ. Impaired wound-healing, local eczema, and chronic inflammation following titanium osteosynthesis in a nickel and cobaltallergic patient: a case report and review of the literature. J Bone Joint Surg Am. 2011;93:e61.

9. Gao X, He RX, Yan SG, Wu LD. Dermatitis associated with chromium following total knee arthroplasty. J Arthroplasty. 2011;26:665.

10. Thomsen M, Rozak M, Thomas P. Pain in a chromium-allergic patient with total knee arthroplasty: disappearance of symptoms after revision with a special surface-coated TKA: a case report. Acta Orthop. 2011;82:386-8.

11. Thyssen JP, Jakobsen SS, Engkilde K, Johansen JD, Soballe $\mathrm{K}$, Menne T. The association between metal allergy, total hip arthroplasty, and revision. Acta Orthop. 2009;80:646-52.

12. Carlsson A, Moller H. Implantation of orthopaedic devices in patients with metal allergy. Acta Derm Venereol. 1989;69:62-6.
13. Schalock PC, Menne T, Johansen JD, Taylor JS, Maibach HI, Liden C, Bruze M, Thyssen JP. Hypersensitivity reactions to metallic implants-diagnostic algorithm and suggested patch test series for clinical use. Contact Dermatitis. 2012;66:4-19.

14. Granchi D, Cenni E, Giunti A, Baldini N. Metal hypersensitivity testing in patients undergoing joint replacement: a systematic review. J Bone Joint Surg Br. 2012;94:1126-34.

15. Akins RB, Tolson H, Cole BR. Stability of response characteristics of a Delphi panel: application of bootstrap data expansion. BMC Med Res Methodol. 2005;5:37.

16. Okoli C, Pawlowski SD. The Delphi method as a research tool: an example, design considerations and applications. Inf Manage. 2004;42:15-29.

17. McKenna H, Hasson F, Smith M. A delphi survey of midwives and midwifery students to identify non-midwifery duties. Midwifery. 2002;18:314-22.

18. Broomfield D, Humphris GM. Using the Delphi technique to identify the cancer education requirements of general practitioners. Med Educ. 2001;35:928-37.

19. Malone DC, Abarca J, Hansten PD, Grizzle AJ, Armstrong EP, Van Bergen RC, Duncan-Edgar BS, Solomon SL, Lipton RB. Identification of serious drug-drug interactions: results of the partnership to prevent drug-drug interactions. J Am Pharm Assoc (2003). 2004;44:142-51. 